\title{
Tendency of exports technology structure and exports concentration in the Balkan economies 2000-2012
}

\author{
Article history \\ Received: 12 . July 2013 \\ Sent for revision: 12 . July 2013 \\ Received in revised form: 27. August 2013 \\ Accepted: 04. September 2013 \\ Available online: 06. November 2013
}

\begin{abstract}
The aim of this paper is to define the quality of export and exports specialisation in the Balkan economies from 2000 to 2012. The research results may contribute to the understanding of economic trends in the countries of the region and at the same time provide guidelines in estimating future economic trends. Quality of exports is measured through the share of goods of higher levels of processing. The methodology of research is based on the Export Concentration Ratio which reflects the degree to which a country's exports are concentrated on a small number of products. The research results showed that in spite of a tendency of mild improvement of the quality of exports of Balkan countries 2000-2012, the quality level of exports from Balkan economies lags greatly behind the countries in the EU and to a lesser extent the Central European economies in transition, with some signs of catching-up. The stagnant and relatively high levels of Export concentration ratio and low share of high processing goods are indicating that Balkan economies are increasingly specializing in price-sensitive markets. For export success it is of great importance to have the transfer of modern technology and investment, especially through FDI, in competitive sectors which would 'spread' export offer. One of the keys for Balkan countries' weak export lies in absence of the mix of science, education and industrial policies, which should be able to promote innovation, product quality and higher technological standards.
\end{abstract}

Keywords: Balkan economies, medium- and high-tech products, skillintensive manufactures, Export concentration ratio.

\footnotetext{
${ }^{1}$ Research Associate, Institute of European Studies, Belgrade, goranvnikolic@gmail.com
} 
Nikolić G.: Tendency of exports technology structure and exports concentration in the..

\section{Tendencije tehnološke strukture izvoza i koncentracije izvoza balkanskih ekonomija 2000-2012}

Apstrakt: Cilj ovog rada je utvrdivanje dostignutog kvalitativnog nivoa izvoza i stepena izvozne specijalizacije u balkanskim ekonomijama od 2000 do 2012. Rezultati istraživanja mogu doprineti razumevanju ekonomskih kretanja $u$ zemljama regiona, istovremeno pružajući smernice u proceni budućih ekonomskih kretanja. Nivo kvaliteta izvoza je utvrđivan kroz učešće robe viših faza prerade u ukupnom izvozu. Metodologija istraživanja zasniva se na izračuavanju koeficijenta koncentracije izvoza koji odražava stepen do kog je izvoz date zemlje koncentrisan na određen broj proizvoda. Rezultati istraživanja su pokazali da je, uprkos tendenciji blagog poboljšanja kvaliteta izvoza balkanskih zemalja 2000-2012, kvalitatativni nivo izvoza balkanskih zemalja u velikoj meri u zaostatku za zemljama EU, a u manjoj meri i za državama Centralne Evrope u tranziciji, istina sa nekim znacima smanjivanja te razlike. Stagnantan i relativno visok nivo koeficijenta koncentracije izvoza kao i nisko učešće roba visokih faza prerade pokazuju da se ekonomije Balkana sve više specijalizovane na cenovno senzitivnim tržištima. Za uspeh na planu izvoza od ključnog značaja su transfer savremene tehnologije $i$ investicije, posebno kroz SDI, i to u kompetitivne sektore koji bi "proširili" izvoznu ponudu datih zemalja. Jedan od ključnih razloga za slbe izvozne performanse balkanskih zemalja leži u odsustvu adekvatnog miksa nauke, obrazovanja $i$ industrijske politike, koja bi trebalo da bude u stanju da promoviše inovativnost, kvalitet proizvoda i veće tehnološke standarde.

Ključne reči: Balkanske ekonomije, visoko i 'srednje-visoko' tehnološki proizvodi, industrijski proizvodi intenzivni ljudskim kapitalom, koeficijent koncentracije izvoza.

\section{Introduction}

A relatively low level of exports and quality of exports structure of the Balkan countries are both a cause and a consequence of poor state of Balkan economic development. Taking into account relevance of exports for the state of economy, an analysis of trends and structural changes in exports may provide useful insights, but may also provide guidelines in estimating future economic trends. Therefore, analysis of the quality of export and exports specialisation in the Balkan economies at the beginning of the 21 st century (from 2000 to 2012) may contribute to the understanding of economic trends in the countries of the Balkan region.

Objective of this paper is to analyse and compare the absolute level and trend regarding the products with higher processing content in total merchandise 
Nikolić G.: Tendency of exports technology structure and exports concentration in the..

exports of eleven Balkan countries (Bulgaria, Greece, Slovenia, Romania, Turkey, Macedonia, Croatia, Serbia, Bosnia-Herzegovina, Montenegro and Albania), which is a good indicator of the quality of total exports structure. Eventually the increasing trend of products with higher processing content in total exports would indirectly indicate an opportunity for these economies to make progress in their competitiveness level. The second objective of this paper is to calculate the indices of Balkan countries' export concentration. Comparative analysis of changes in these indices may point to future qualitative and quantitative changes in exports of Balkan countries.

First aim of this paper is to analyse the changes of technological structure of Balkan countries' export according to technology structure. Export is divided into the two categories: first are medium- and high-tech products, and second are all other products. It is important that former category is a good indicator of the quality of exports. The potentially high achieved share of technology intensive products in total export and eventually increases of such share would indirectly indicate a qualitative improvement of merchandise exports.

One of the objectives of this paper is to analyse and compare the absolute level and trend of the share of skill-intensive manufactures in total merchandise exports of Balkan countries, which is a good indicator of the quality of exports structure. The level and potential increases of such share would indirectly indicate a qualitative improvement of merchandise exports. The share of skill-intensive manufacturers in exports and the increasing trend of such share would indirectly indicate an opportunity for these economies to make progress in the level of competitiveness.

Our hypothesis is that in the period observed, from 2000, technological structure (and skill intensity) of exports of Balkan countries shifted towards an increased share of products with higher processing (as was the case in the advanced transition economies since mid-nineties, that is Central European economies). First, we test the hypothesis about the possible structural improvement of exports of Balkan countries by classifying the exports, according to technology structure, into the two categories: medium- and high tech products and all other products (medium- and high tech level includes some machinery and electrical equipment and telecommunications, pharmaceuticals, computers and office machinery, and some precision instruments). Second, we test identical hypothesis by classifying the total exports into the categories of skill-intensive manufactures and all other products. An eventually growing share of these products in total exports would suggest a qualitative improvement of the exports of Balkan countries, given the higher share of products with higher processing in exports of developed countries.

The results of this research will help clarify the trends in the structural change of exports of the Balkan countries and the quality level of exports achieved in 
Nikolić G.: Tendency of exports technology structure and exports concentration in the..

each of the observed countries. The aim is to identify the deficiencies in exports from the observed Balkan countries as development of economic and exports structures is an essential prerequisite for competitiveness, particularly within the EU market. Insight into the achieved level (and trend) of high processing products in total exports (which is also a reflection of the state of the overall economy) can facilitate our work on the conceptualization of measures in order to promote Balkan countries' exports.

The second aim of this paper is to calculate the indices of Balkan countries' export concentration (using Herfindahl-Hirschmann concentration index for the period 2001-2011). Comparative analysis of changes in these indices may point to future qualitative and quantitative changes in exports of Balkan countries. Our second hypothesis is that in the period 2001-2011 export specialisation indices in majority of Balkan countries is decreased (same tendency was recorded in European countries in transition, as well as developed economies). Diversification of export is expected as a corollary of export structure's improvement.

\section{Literature Rewiew}

There is extensive literature on the structural changes in Central and Eastern European Countries exports during two previous decades. In study by Ivashko and College (2012) was explored the impact that entry to the EU has on the trade structures of Eastern European countries, particularly Czech Republic and Romania (from 1999 to 2009). In the case of Romania, while apparel maintained competitive status despite its huge drop in RCA, the country saw growth in electrical machinery and vehicle. Analysis of Romanian trade structure showed an immediate shift from apparel manufacturing in which, until recently, it had experienced competitive advantage, towards the industrial sectors. Romania, which entered its pre-accession period with a "developing trade structure", experienced a drastic change in trade structure.

La (2011) empirically investigates the extent to which technological characteristics in exports affect the patterns of trade-led economic growth across countries. Regression results based on a sample of 71 countries since 1970 suggest that economies have tended to grow more rapidly when they have increasingly specialized in exporting high-technology as opposed to traditional or low-technology goods.

Aydin (2007) showed that commodity concentration of Turkey' exports increased after 2001, thanks to the expansion of exports of new nontraditional commodities. 
Nikolić G.: Tendency of exports technology structure and exports concentration in the..

Doanh (2012) analyse export specialisation in South Korea in the period 1997-2010. The results show that there is a movement towards specialization, when merchandise export of Korea is considered.

In study by Camanho, Neto \& Romeu (2011) is considered the role of export diversification in determining trade outcomes during the global financial crisis. The impact of export concentration is measured by assessing three different dimensions of specialization, among others the commodity (merchandise) concentration. To estimate the impact of having greater trade diversification the study employs a trade dataset disaggregated at the four digit level of the Harmonized System of classifying trade (the same as this study does). The results presented suggest that product diversification attenuated the trade collapse. In addition, preliminary evidence is presented suggesting that concentration in commodities helped smooth the collapse in exports.

\section{Theoretical Methodology}

\subsection{Export classifications according to technological structure}

When tendency of technology structure is concerned the literature dealing with virtually the same methodology was listed in a study by Munkacsi (2011). Possible structural improvement of CEEC' exports Munkacsi calculated by classifying the exports into the five categories: resource based, low-tech, medium - and high-tech. He classifies the products (by SITC, 3 digit level, Revision 4) into four categories relating to the technology level of the products. $^{2}$

SITC two or three digit categories, which are sorted as medium - and hightech, are: merchandise group 266 and 267, section 5 - Chemicals and related products (5 less $52,551,592), 653$, divisions 67 - Iron and steel (67 less 673 , $674,675,676,677$ ), section 7 (Machinery and transport equipment), divisions 81 (Prefabricated buildings; sanitary plumbing, heating and lighting fixtures and fittings), Professional, Scientific, Controlling Material (divisions 87), Photographic Apparatus, Optical Goods, Clocks (divisions 88). In our calculation, because of incomplete availability of data, we take in account all two digit SITC category and some three 3-digit SITC category.

Analysis of share of skill-intensive manufactures in total exports (and imports), is given in study by Mayer and Wood (2001). World-wide cross-country regressions are used to examine South Asia's export structure through the lens of Heckscher-Ohlin trade theory. Export structure, based on labourintensive manufactures, is shown to be the result mainly of South Asia' $s$

\footnotetext{
${ }^{2}$ Clasification by Munkacsi is based on Industrial Development Report (UN, 2009).
} 
Nikolić G.: Tendency of exports technology structure and exports concentration in the..

distinctive combination of resources (it has a low level of education and few natural resources, relative to its supply of labour). Limited integration of South Asia with the world economy is in sharp contrast to the successful exportoriented industrialization of East Asia, which has significantly higher share of skill-intensive manufactured goods in total exports. This paper seeks to shed light on this contrast, and to contribute to trade and development strategy in South Asia, by examining and explaining the structure of the exports of both Asian regions in a world-wide comparative context. The central hypothesis of the paper is that differences among countries in the broad features of their export structure are the result mainly of differences in supplies of human and natural resources differences which, moreover, change over time only slowly.

Mayer and Wood (2001) divide merchandise exports into two broad categories: manufactured and primary. Definition of manufactures is the one used by trade statisticians, namely categories 5,6,7,8 without 68 (non-ferrous metals) of the Standard International Trade Classification - SITC (Beside this, the SITC 5, 61-67, 69, 7, 8 categories allocated to primary rather than manufactured exports are phosphorus pent-oxide and phosphoric acids (522.24), aluminium hydroxide (522.56), radioactive material (524), pearls and precious stones, except cut diamonds (667 except 667.29)). Mayer and Wood (2001), in addition to this, emphasize a few things: "This definition (of manufactures) is something narrower than that used by production and employment statisticians, who also count as manufactures natural-resourcebased products made in factories, such as canned food. After that, narrow manufactured exports is sub-divided between labour-intensive items and skillintensive items, which was based on a review of earlier studies that ranked individual manufacturing industries by their skilled/unskilled labour ratios or other measures of skill intensity (e.g. the study reviewed in Wood, 1994, Chapter 3). According to mentioned authors: textiles, clothing, footwear, leather and wood products are classified as labour intensive, and chemicals, machinery, cars, aircraft and instruments as skill-intensive. A limitation of any classification of manufactured exports by skill intensity is the internal heterogeneity of statistically defined industries. Each industry contains many goods (final and intermediate) and many activities (or stages of production) of widely varying skill intensity, which are increasingly divided among countries (for example, in the electrical machinery sector skill-intensive components are made in developed countries and labour-intensive assembly is undertaken in developing countries. Thus, the same 'good', in a statistical sense, may vary widely in skill intensity, depending on the country from which it is exported."

It is important for this study that SITC two (three or five) digit categories, which are sorted as skill-intensive manufactures, are: Chemicals (5 less 522.24, 522.56, 524), Cut diamonds (667.29), Non-electrical machinery (71, $72,73,74)$, Computers and office equipment (75), Communication equipment (76), Electrical machinery (77), Motor vehicles (781, 782, 783, 784), Aircraft 
Nikolić G.: Tendency of exports technology structure and exports concentration in the..

(792), Professional, Scientific, Controlling Material (87), Photographic Apparatus, Optical Goods, Clocks (88). In our calculation, because of incomplete availability of data, we take in account all two digit SITC category and only three 3-digit SITC category (785-Motorcycles/cycles/ETC; 786Trailers/caravans/ETC; 792-Aircraft/spacecraft/ETC), having in mind somewhat balancing, and in any case rather miniscule share of other categories of SITC (Revision 4). ${ }^{3}$

There are number of similar classifications. In IMF' publication (2011) OECD Measure of Trade by Technology Intensity were presented. OECD provides four categories of technological intensity: high, medium high, medium low, and low technology. The technological intensity reflects to some degree a 'technology-producer' aspect, measured by the ratio of R\&D expenditure to value added, and a 'technology-user' aspect, measured by purchases of intermediate and capital goods. In line with the above-mentioned classification manufacturing industries classified according their global technological intensity, which belong to high and medium high technology are: aerospace, pharmaceuticals, computers, office machinery, electronics-communications, precision instruments, electrical machinery, motor vehicles, chemicals, other transport equipment, and machinery and equipment.

\subsection{Calculation of Export concentration ratio and examples where the same methodology is applied}

The Export Concentration Ratio (Cxj), also known as the HerfindahlHirschmann index, is most commonly used ways of measuring export concentration. The Herfindahl-Hirschmann coefficient is the numerical expression of concentration; the higher the coefficient is the lower level of diversification it represents. Export concentration reflects the degree to which a country's exports are concentrated on a small number of products (or countries). The index is the simplest and most affordable indices due to their ease of comprehension and availability of data.

The Export Concentration Ratio (ECR) as defined by UNCTAD only measures merchandise exports and does not include exports of services. The ECR ranges from 0 to 1 , with 0 reflecting the least concentrated export portfolio and 1 the most concentrated (UNCTAD Handbook of Statistics, 2009). A country that exports one product has a perfectly concentrated export portfolio. Conversely, a country whose exports are comprised of a larger number of products has a lower export concentration ratio, i.e., has more diversified

\footnotetext{
${ }^{3}$ SITC (Revision 4) detailed clasification can be found in UN Publication, "Standard International Trade Classification (Revision 4)", Department of Economic and Social Affairs, Statistics Division, UN, Statistical Papers Series M No. 34/Rev. 4, 2006. pp: XXIII, 2-178.http://unstats.un.org/unsd/trade/sitc\%20rev\%204\%20final.pdf
} 
Nikolić G.: Tendency of exports technology structure and exports concentration in the..

exports. The index is normalised because of number of merchandise products is different between countries.

$$
C_{x j}=\frac{\sqrt{\sum_{i=1}\left(\frac{X_{i j}}{X_{j}}\right)^{2}}-\sqrt{\frac{1}{n}}}{1-\sqrt{\frac{1}{n}}}
$$

Where:

$\mathrm{i}=1 \ldots \mathrm{n}$

$\mathrm{n}=$ number of $\mathrm{H}-\mathrm{S} 4$ digit export categories (about 1200)

$\mathrm{X}_{\mathrm{ij}}=$ value of export of sector "i" from the country "j" in a given year

$\mathrm{X}_{\mathrm{j}=}$ total export volume of the relevant country in the same year

We used International Trade Center Harmonized System (HS) product cluster at 4-digit. In that part of paper we seek to empirically examine the patterns and dynamics of Balkan countries' export specialization in the period 20012011. The logic of export specialization was originally developed to explain the underlying reasons for international trade and predict the trade pattern resulting from changes in factor endowment and technology. Accordingly, free trade would allow countries to gain from increasing specialization in activities where they have comparative advantage under autarky. Seeking for this aim, we focus on the following research objectives: to assess the patterns and dynamics and degree of Balkan countries' export specialization and to derive policy implications based on the empirical findings.

It should be noted that concentration of exports on few commodities is usually considered as a potential problem for economies to sustain long run high export growth, since fluctuations in export commodity prices may also increase volatility in export receipts of a country. Herfindahl-Hirschmann index shows a very high value in countries with high exports of primary products (e.g. crude oil) while the index is very low in developed countries. Decline in export concentration ratios was a tendency in almost all countries in the period after World War II, especially in the last two decades of the 20th century. Otherwise, it is natural that smaller countries have higher ratios of exports because they can't sufficiently diversify their export offer. In former socialist countries a relatively low coefficient of export concentration is a consequence, among other things, of the forced industrialization which involved a wide range of industrial sectors without significant specialization.

Gökhan Saz (2011) analyse the European integration of the Turkish industry in view of a comparative trade analysis of the Turkish and the EU economies. In order to quantify the recent diversification of the export markets of Turkey 
Nikolić G.: Tendency of exports technology structure and exports concentration in the..

authors used a concentration measure known as the Herfindahl-Hirschmann index and Gini-Hirschman index, as originally developed by Hirschman (1945).

Jung Joo La (2011) used three existing export market diversification indices, among others, the Herfindahl-Hirschman Index.

In study by Camanho, Neto \& Romeu (2011) is considered the role of export diversification in determining trade outcomes during the global financial crisis. The impact of export concentration is measured by assessing three different dimensions of specialization, among others the commodity concentration. To estimate the impact of having greater trade diversification, the study employs a trade dataset disaggregated at the four digit level of the Harmonized System of classifying trade (as in this study).

\section{Used Data}

In this paper we use the structure of exports by SITC (Standard International Trade Classification, Revision 4) to a two, that is, three digit level for ten Balkan countries (Turkey, Bulgaria, Greece, Slovenia, Romania, Croatia, Serbia, Bosnia-Herzegovina, Macedonia, Montenegro), external EU27, and U.S. (data for Albania on that level of classification, unfortunately, we were unable to obtain, but we used 1-digit SITC). We have observed period from 2000 to 2012.

Primarily International Trade Center data and national statistical offices' databases are used. Share of merchandise divisions (SITC, 2-digit level) is sourced from national statistics and publications of EUROSTAT. Share of some SITC merchandise group, e.g. 266, 267, 512, 513, 533, 551, 592, 653, $671,672,678,785,786$ and 792 is indirectly sourced from International Trade Center (http://www.intracen.org). ${ }^{4}$ Conversion from HS (4-digit) classification by Trade Map (International Trade Center) to SITC (3-digit) is made according to Correspondence table between the basic headings of SITC (Revision 4) and the subheadings of the Harmonized Commodity Description and Coding System $(2007)^{5}$.

When Export concentration ratio is concerned we have used International Trade Center HS product cluster at 4-digit level (which practically has about 1200 products). Harmonized Commodity Description and Coding Systems (Harmonized System - HS) is an international nomenclature for the classification of products. It allows participating countries to classify traded

\footnotetext{
${ }^{4}$ http://www.trademap.org/countrymap/Product_SelCountry_TS.aspxcalculated

${ }^{5}$ http://unstats.un.org/unsd/trade/sitcrev4.htm
} 
Nikolić G.: Tendency of exports technology structure and exports concentration in the..

goods on a common basis for customs purposes. We calculated Export concentration ratio for 11 (all) Balkan countries, Italy, Germany, and U.S.

\section{Results and analysis of results}

Using the previously mentioned methodology we obtained the results shown in Tables 1, 2 and 3. When it comes to Table 1 and 2 we were not able to get to the data for Albania.

According to Tables 1 and 2 it can be seen that from 2000 to 2012 the majority of observed Balkan countries detected an increase of medium- and high-tech products in total merchandise exports. Practically identical situation is with the skill-intensive manufactures (of course there are exceptions, such as Greece and B\&H)._Looking at the absolute level, as expected, EU and U.S. have the best results. In U.S. medium- and high-tech products accounted for almost $56 \%$ of total exports in 2012, while skill-intensive manufactures accounted for half of total exports in 2012 (in the previous years the proportion was generally higher). ${ }^{6}$ Looking at EU the medium- and high-tech products accounted for almost $61 \%$ of external exports in the 2011 , while skillintensive manufactures accounted for almost $59 \%$ of external exports in the 2011.

Table 1. Tendency of share of medium- and high-tech products in total merchandise exports 2000-12 (as \%)

\begin{tabular}{|c|c|c|c|c|c|c|c|c|c|c|c|c|c|}
\hline & 2000 & 2001 & 2002 & 2003 & 2004 & 2005 & 2006 & 2007 & 2008 & 2009 & 2010 & 2011 & 2012 \\
\hline Greece & 21,3 & 22,2 & 25,2 & 26,5 & 28 & 28,1 & 27,4 & 26,2 & 28,1 & 28,7 & 27,2 & 20,5 & 18,7 \\
\hline Macedonia & - & - & - & - & - & 12,1 & 11,4 & 11,6 & 12,5 & 14,8 & 19,8 & 26,6 & 29 \\
\hline Turkey & 26,7 & 28,9 & 30 & 32,2 & 35,1 & 35,5 & 37,3 & 38,4 & 36,4 & 35,4 & 35,7 & 35,5 & 31,9 \\
\hline Croatia & 42,0 & 43,2 & 42,5 & 42,6 & 45,3 & 43,0 & 41,5 & 44,2 & 46,8 & 43,0 & 46,5 & 44,4 & 40,6 \\
\hline Romania & 28,6 & 29,1 & 30,3 & 30,8 & 33,7 & 35,4 & 39,5 & 44,0 & 46,1 & 52,5 & 52,3 & 51,5 & 51,0 \\
\hline $\mathrm{B} \& \mathrm{H}$ & - & - & - & 29,1 & 24,5 & 25,1 & 24,5 & 24,9 & 25,5 & 26,5 & 24,2 & 24 & 25,4 \\
\hline Serbia & 23,5 & 22,1 & 20,9 & 30,5 & 22,2 & 21,5 & 22,3 & 25,8 & 28,5 & 28,0 & 26,7 & 26,9 & 31,2 \\
\hline Montenegro & - & - & - & - & - & - & 8,5 & 12,7 & 15,3 & 10,3 & 6,9 & 8,5 & 6,8 \\
\hline Bulgaria & 21,9 & 23,8 & 23,1 & 24,3 & 22,6 & 23,6 & 22,3 & 25,0 & 25,7 & 26,8 & 26,7 & 26,4 & 26,4 \\
\hline Slovenia & 58,5 & 57,3 & 60,5 & 61,5 & 59,5 & 60,0 & 58,6 & 59,9 & 60,0 & 58,9 & 58,2 & 56,5 & 55,8 \\
\hline Extra EU27 & 64,2 & - & - & - & - & - & - & - & - & 61,9 & 62,1 & 61,2 & - \\
\hline U.S. & 67,9 & - & - & - & - & - & - & - & 59,5 & 60,5 & 58,9 & 56,2 & 55,3 \\
\hline
\end{tabular}

Source: Authors calculation.

\footnotetext{
${ }^{6}$ Among other factors, a sharp drop in exports of aircraft and spacecraft (792) reduced the share of skill-intensive manufactures (in 2011 the share of aircraft and spacecraft was only $0,5 \%$ of total exports, which is 13 times less than in 2007 , before the outbreak of the global economic crisis).
} 
Nikolić G.: Tendency of exports technology structure and exports concentration in the..

Table 2. Share of skill-intensive manufactures in total merchandise exports and imports 2000-12 (as \%)

\begin{tabular}{|c|c|c|c|c|c|c|c|c|c|c|c|c|c|}
\hline & 2000 & 2001 & 2002 & 2003 & 2004 & 2005 & 2006 & 2007 & 2008 & 2009 & 2010 & 2011 & 2012 \\
\hline Greece & 19,3 & 21 & 23,3 & 24,5 & 26,4 & 26 & 26,2 & 25,1 & 25,1 & 25,5 & 25 & 19,5 & 17,7 \\
\hline Macedonia & - & - & - & - & - & 9,1 & 8,5 & 8,1 & 9,3 & 12,3 & 17,4 & 24,9 & 26,7 \\
\hline Turkey & 24,8 & 26,2 & 27,3 & 29,3 & 31,9 & 31,7 & 33,9 & 34,6 & 32,2 & 31,6 & 33 & 32,8 & 30,0 \\
\hline Croatia & 25,9 & 25,5 & 27,3 & 27,7 & 29 & 29,1 & 27,2 & 29,8 & 31,1 & 32,4 & 31,5 & 30,5 & 30,9 \\
\hline Romania & 21,8 & 22,4 & 23 & 23,6 & 26,6 & 28,5 & 32,7 & 36,3 & 38,9 & 44,1 & 46,1 & 45,9 & 45,1 \\
\hline $\mathrm{B} \& \mathrm{H}$ & - & - & - & 20,3 & 17,6 & 19,9 & 18 & 18,6 & 19,7 & 19,2 & 17,1 & 17,7 & 18,4 \\
\hline Serbia & 22,5 & 20,8 & 19,9 & 20,2 & 21,5 & 20,8 & 20,8 & 23,8 & 25,4 & 24,0 & 24,0 & 24,3 & 28,2 \\
\hline Montenegro & - & - & - & - & - & 7,2 & 8,5 & 7,6 & 9,7 & 16,4 & 13,8 & 11,1 & 11,3 \\
\hline Bulgaria & 21,8 & 22,2 & 21,8 & 22,3 & 20,2 & 20,7 & 19,5 & 23,3 & 24,2 & 25,4 & 25,4 & 25,7 & 25,3 \\
\hline Slovenia & 48,3 & 48,4 & 50,2 & 51,0 & 51,6 & 52,8 & 52,2 & 54,4 & 54,5 & 57,4 & 56,5 & 53,8 & 55,0 \\
\hline Extra EU27 & 60,6 & - & - & - & - & - & - & - & - & 59,7 & 59,7 & 58,8 & - \\
\hline U.S. & 68,6 & - & - & 64,9 & - & - & - & - & 58,9 & 54,0 & 53,9 & 51,5 & 50,1 \\
\hline
\end{tabular}

Source: Authors calculation.

In Table 3 it is obvious that Herfindahl-Hirschmann index grew after the initial decrease and has maintained a relatively high level ever since. HerfindahlHirschmann level generally represents a poor diversification of Balkan countries' economies. The overall development suggests that the level of export diversification has not come to significant improvements. United States and Italy have very low Herfindahl-Hirschmann index which is in line with advanced export structure. Italy, a country with Germany's most important export partner almost all the Balkan economies, had consistently low coefficient, which has increased slightly in the last years. Germany has a nearly constant level Herfindahl-Hirschmann, which is slightly higher than the same index for Italy or the U.S., as a result of higher exports of some sophisticated products, such as cars.

Table 3. Exports concentration ratio (Herfindahl-Hirschmann index), Balkan countries 2001-11

\begin{tabular}{|c|c|c|c|c|c|c|c|c|c|c|c|}
\hline & 2001 & 2002 & 2003 & 2004 & 2005 & 2006 & 2007 & 2008 & 2009 & 2010 & 2011 \\
\hline Turkey & 0,0858 & 0,0918 & 0,0975 & 0,1049 & 0,1015 & 0,1074 & 0,104 & 0,1138 & 0,096 & 0,0857 & 0,0859 \\
\hline Croatia & 0,1679 & 0,1501 & 0,1441 & 0,1397 & 0,1415 & 0,1458 & 0,1428 & 0,1429 & 0,1187 & 0,1328 & 0,1356 \\
\hline Romania & 0,1175 & 0,1152 & 0,1233 & 0,1189 & 0,1323 & 0,1282 & 0,1198 & 0,1179 & 0,1196 & 0,1186 & 0,1195 \\
\hline $\mathrm{B} \& \mathrm{H}$ & - & - & 0,2867 & 0,1944 & 0,1496 & 0,1393 & 0,1270 & 0,1168 & 0,1175 & 0,1198 & 0,1126 \\
\hline Serbia & 0,1042 & 0,1110 & - & 0,1130 & 0,1147 & 0,1118 & 0,0955 & 0,0948 & 0,0824 & 0,0929 & 0,0846 \\
\hline Monten. & - & - & - & - & - & 0,5620 & 0,5432 & 0,4240 & 0,3950 & 0,3825 & 0,4017 \\
\hline Bulgaria & 0,1246 & 0,1087 & 0,1025 & 0,1120 & 0,1240 & 0,1503 & 0,1355 & 0,1404 & 0,1123 & 0,1236 & 0,1251 \\
\hline Slovenia & 0,0993 & 0,1051 & 0,1066 & 0,1104 & 0,1230 & 0,1127 & 0,1286 & 0,1193 & 0,1374 & 0,1263 & 0,1172 \\
\hline Greece & 0,1130 & 0,0981 & 0,0967 & 0,0967 & 0,1124 & 0,1320 & 0,1235 & 0,1103 & 0,1047 & 0,1155 & 0,2737 \\
\hline Albania & 0,2611 & 0,2752 & 0,2688 & 0,2298 & 0,2066 & 0,1797 & 0,1597 & 0,1438 & 0,1479 & 0,1586 & 0,1871 \\
\hline Macedonia & 0,1391 & 0,1365 & 0,1455 & 0,1504 & 0,1584 & 0,1634 & 0,2062 & - & 0,2583 & - & 0,1801 \\
\hline Germany & 0,1174 & 0,1219 & 0,1318 & 0,1240 & 0,1131 & 0,1070 & 0,1173 & 0,1103 & 0,1132 & 0,1159 & 0,1102 \\
\hline Italy & 0,0954 & 0,0960 & 0,0984 & 0,0972 & 0,1002 & 0,0994 & 0,1001 & 0,1023 & 0,0980 & 0,1010 & 0,1025 \\
\hline U.S. & 0,0915 & 0,0913 & 0,0887 & 0,0846 & 0,0832 & 0,0838 & 0,0824 & 0,0806 & 0,1063 & 0,1012 & 0,1038 \\
\hline
\end{tabular}

Source: Authors calculation.

The previous tables shown that the mild structure' improvements is achieved from 2000 to 2012. In addition, as is expected, Central European countries (like Slovenia) or developed economies (e.g. the U.S. or the EU) have a 
Nikolić G.: Tendency of exports technology structure and exports concentration in the..

higher level of high processing export products in total than mentioned Balkan economies. This could be seen through the share of skill-intensive manufactures (or share of high and medium high exports) in total exports. When Export concentration ratio is concerned the situation is also better in developed economies. In spite of that, positive changes are visible.

Generally, from 2000 to 2012 the majority of observed Balkan countries detected an increase of medium- and high-tech products in total merchandise exports (Table 1). Romania performed with the best results, while certain countries, like Bosnia-Herzegovina, have a stagnant exports structure (Montenegro is a specific case, due to a large share of non-ferrous metals in total exports). Comparing with other Balkan countries, Croatia has practically constant high level of medium- tech and high-tech products in total merchandise exports. Progress of Turkey was evident in first seven years of last decade, while in last half decade, excluding probably incidental fall in the 2012, export structure is factually constant. Looking at the absolute level, as expected, EU and the U.S. have the best results. Serbia recorded mild growth of share of medium- and high-tech products during observed period. Sudden and significant growth during 2003 can be partially attributed to a strong growth in the share of sector 79 in total exports, which is a consequence of the "problematic" inclusion of ship and airplane repairs.

According to Table 2 it can be seen that from 2000 to 2012 the majority of observed Balkan countries run an increase of skill-intensive manufactures in total merchandise exports. Romania has best figures. Certain countries, like Croatia or Bosnia-Herzegovina, have a stagnant exports structure. Looking at the absolute level, as expected, the EU and the U.S. have the best results.

According to table 3 it is visible that in the period after 2001 there were different movements of Export concentration ratios in Balkan economies. Herfindahl-Hirschmann index is relatively high, which represents poor diversification. In the majority of Balkan economies situation has mildly improved towards the end of the period and the overall development can thus be perceived as slightly positive, even though the level of concentration remained high, comparatively observed. Even though the long-term linear trend line of the whole 11 year period is, in the case of the HerfindahlHirschmann coefficient, aiming slightly downwards. The index is lower, that is situation is, as expected, better in the United States, Germany, and especially Italy.

To summarize, in tables 1, 2 and 3 some improvement of export structure of Balkan countries can be detected. First, from 2000 to 2012 the majority of observed Balkan countries run an increase of medium- and high-tech products in merchandise exports. The identical situation is with share of skillintensive manufactures in total exports. When export concentration ratio is concerned the mild growth between 2001 and 2011 is detected. 
Nikolić G.: Tendency of exports technology structure and exports concentration in the..

Practically in all of the Balkan countries since 2000 there has been a change in the technological structure and factor intensity of foreign trade in the direction of increasing higher processing products (the same was the case in the advanced transition countries since the 1990s). In spite of that, the share of that products equalled about $30 \%$ of total exports in Balkan countries (2012) which is still significantly lower than the share of identical group of products in developed or advanced transitional countries. For example, the share of skill-intensive manufactures in Balkan countries excluding Slovenia and Romania (while Montenegro and Albania have very low share of skillintensive manufactures) is almost two times lower than in developed countries (Nikolić, 2010). The factually identical situation is with the tendency and recent share of medium- and high-tech products in merchandise exports.

Balkan countries' small share of higher processing products indicates a poorly developed technological base and an outdated production technology.

Previous analysis had shown that the strong absolute growth in Balkan countries' exports is occurring along with a mild increase of share higher processing products in exports. Looking at the structure of total merchandise exports after 2000, it is easily noticeable that share of labour and resource intensive products, although declining, is still high.

When export concentration ratio' tendency is concerned there are minimal improvements. To be precise, the index in most Balkan countries is substantially unchanged compared to 2001 . The relatively low value of the coefficient (except in B\&H, Greece, Albania and Macedonia) similar to that of developed countries, is not indicators of a broad range of export goods in Balkan economies and their advanced structures, but, above all, the absence of certain competing products.

\subsection{Analysis of results by countries}

In Romania the share of medium- and high-tech products in total merchandise exports was strongly growing from 2000 to 2012 (with 28,6\% to 51\%). Excluding stagnancy during last four years this increasing trend was practically uninterrupted. Also, the increasing and relatively high share of skillintensive manufactures (whose share in total exports doubled) is an impartial indicator of the Romanian economic achievement. Reason for that tendency is the increase in the share of exports of Road Vehicles (division 78), which was doubled in 2012 compared to 2006, increasing more than ten-fold in 2000-2012 period. Another positive economic result occurred as a consequence of the exports growth of Electrical machinery and apparatus (division 77), which share had a triple increase in the same period (to about a ninth of exports in recent years). During 2012 the growth of exports of electrical equipment and cars positively affected share of skill-intensive 
Nikolić G.: Tendency of exports technology structure and exports concentration in the..

manufactures and share of medium- and high-tech products in total exports (accounting for $28.2 \%$ of total exports, which is eight percentage points higher than a decade ago). After the initial increase of the Herfindahl-Hirschmann index between 2002 and 2005, the indicator slightly decreased, to be stabilized after 2006. First ten products (HS 4 digit) make $38.2 \%$ of total exports in the 2011 (first three products, which account for almost $18 \%$ of total exports, are: parts for motor vehicles, cars and cables), while that share was only $18.1 \%$ ten years earlier. Stabilisation of Export concentration ratio at the lower level is in line with improved export structure.

From 2000 to 2012, the share of skill-intensive manufactures in total merchandise exports has slightly increased (from $26 \%$ to $31 \%$ ) in Croatia, while tendency of share of medium- and high-tech products in total merchandise exports is similar, excluding 'problematic' 2012. HerfindahlHirschmann index between 2001 and 2011 constantly decrease, even though the level of concentration remained relatively high (comparing with the EU or the U.S.). The exception is the crisis 2009th when Croatia recorded a sharp drop in the concentration of exports, which was caused by a decrease in the share of several product groups, primarily ships and petroleum products. The share of exports of ships fell from $11.5 \%$ to $6.9 \%$ (in 2010 . rose to $7.7 \%$ ), while the petroleum products fell from $9.4 \%$ (2008) to $8.8 \%$ in 2009 (and in next year rose to $10.2 \%$ ).

In Turkey, the share of skill-intensive manufactures in total merchandise exports, after practically continual growth from 2000, achieved a record value in 2007. During the next five years that share decreased slightly. The situation with share of medium- and high-tech products in total merchandise exports is practically identical. After the increase of the Export concentration ratio from 2001 to 2008 the indicator suddenly decreased in last three observed years. Generally speaking the export concentration is low as a result of significant diversification of Turkey's economy.

Macedonia's merchandise exports structure is unfavourable. Share of skillintensive manufactures and share of medium- and high-tech products in total exports is very low, excluding last three years. Namely, after 2009 Macedonia has recorded strong growth of division 59 - Chemical materials and products, n.e.s. (12.4\% of total export 2011/12), which had about 60 times lower share between 2005 and 2008. That spike was a main contributing factor to the increase of skill-intensive manufactures and share of medium- and high-tech products in total exports. Herfindahl-Hirschmann index between 2001 and 2009 reached very high levels, which represents poor diversification. The situation slightly improved in 2011.

The share of medium- and high-tech products in total merchandise exports, as well as skill-intensive manufactures has slightly increased during observed period in Bulgaria. It should be noted that high share of petroleum products 
Nikolić G.: Tendency of exports technology structure and exports concentration in the..

(about 11\%) decelerated growth of share of medium- tech and high-tech products and skill-intensive manufactures in the total merchandise exports (during 2012 that share decreased slightly, after moderate growth in the past five years). After the initial increase of the Herfindahl-Hirschmann index between 2002 and 2016, the indicator decreased. The situation has moderately improved towards the end of the period and the overall development can thus be perceived as slightly positive, even though the level of concentration remained relatively high comparing with developed economies.

Bosnia-Herzegovina has strongly increased the share of petroleum products (SITC 33 divisions) in total merchandise exports since 2008 to 2012 (eleven times), which was a factor of slightly decreasing share of skill-intensive manufactures and share of medium- and high-tech products. Generally speaking, share of skill-intensive manufactures and share of medium- and high-tech products in merchandise exports was very low and stagnant. Even though the Herfindahl-Hirschmann coefficient followed a continuously decreasing trajectory, ending with 2008 , this value is in average extremely high. In last three observed years we can detect stabilization of index on the lower level. The value in 2011 is a significantly lower than in the initial year of observation.

Greece has a relatively low share in skill-intensive manufactures and share of medium- and high-tech products in the total exports. Strong fall of both shares in 2012 (and 2011) is essentially attributable to a very strong exports growth of Division 33 - Petroleum, petroleum products and related materials (which accounted for $35 \%$ of merchandise exports compared to 2010 or 2000 when it made up $11 \%$ and $13 \%$ respectively). Herfindahl-Hirschmann index, excluding 2005 and 2006 when mild increase was detected, has a moderate level. Exception was 2011 (and probably 2012), when Herfindahl-Hirschmann grew strongly and with extremely high value which can be connected with increase of exports of petroleum products.

When Serbia is concerned, share of medium- and high-tech products in total merchandise exports, as skill-intensive manufactures, slightly increased in the period 2000-2012. Tendency is encouraging, but in spite of that both shares are relatively low. Herfindahl-Hirschmann index in Serbia has very low value, especially in last several years. From 2005 decreasing trend was detected. Between 2008 and 2011 the indicator reached very low level which apparently represents a high diversification. More accurate insight into the structure of exports indicates that this is a 'jack of all trades' phenomenon.

From 2007, the share of skill-intensive manufactures in Montenegrin merchandise exports increased from $7.6 \%$ to only $11.3 \%$, while share of medium- tech and high-tech products have decreasing tendencies. Montenegro has extremely high value of Herfindahl-Hirschmann index during 
Nikolić G.: Tendency of exports technology structure and exports concentration in the..

observed period, which represents very poor diversification. The very unfavourable situation has mildly improved towards the end of the period.

Slovenia has relatively high but stagnant share of medium- and high-tech products in total merchandise exports. On the other hand, share of skillintensive manufactures was also high, but slowly growing as of 2009. Both indicators are good indicators of Slovenian exports quality. It is clear that Slovenia has over the 1990s already achieved a high quality level of exports structure, like other advanced transition countries. After the initial increase of the Herfindahl-Hirschmann index between 2001 and 2005 the indicator value has oscillated for next six years. The situation has somewhat improved towards the end of the period (2009-11).

Merchandise exports' structure of Albania is exceptionally unfavourable, the worst in the region. Namely, in the period 2004-2011 (for which we have data on the 1-digit SITC, Revision 4) Albania had a very high proportion of goods that belong to sections 6- Manufactured Foods Classified by Material (mainly lower stages of processing goods, especially products) and 8- Miscellaneous manufactures (average $22,3 \%$ and $49,3 \%$ of total exports, respectively). In contrast, Albania had extremely low share of sections 7- Machinery, Transport Equipment and 5- Chemical Products, which mainly consists of technologically intensive products $(4,1 \%$ and $1,1 \%$, average $2004-2011)$. In Croatia the collective share of these two sections was $41 \%$, in Romania $47 \%$, in Serbia 25\%, while collective share sector 5 and 7 in Albania was 5,3\% 2011 (and $4.5 \%$ seven years earlier). Very small share of sections 5 and 7 , which are technologically intensive products, indicates a poorly developed technological base and an outdated production technology. HerfindahlHirschmann index has very high levels. The situation improved in last half of decade, even though the level of concentration remained very high in all analyzed years.

\section{Conclusion}

The quality level of export products from Balkan countries lags greatly behind the countries in the EU and to a lesser extent the Central European economies, with some signs of catching-up over time (less lag compared to the Central European economies is evident from the above cited studies). The levels of export concentration and low share of high processing goods are indicating that Balkan economies are increasingly specializing in pricesensitive markets.

At the beginning of the 21st century there was a tendency of mild improvement of the quality of exports of majority Balkan countries (there are exceptions, such as Greece, B\&H, Montenegro), which can be traced through 
Nikolić G.: Tendency of exports technology structure and exports concentration in the..

a slight increase in the share of goods of higher levels of processing. When export concentration indicators are concerned in the majority of Balkan economies situation has mildly improved towards the end of the period and the overall development can thus be perceived as slightly positive, even though the level of concentration remained high, comparatively observed. This means that the two initial hypotheses were accepted.

Established export structure is complicating factor for a significant export increase. Therefore, the increase in exports over the last decade (and more) mostly relied on previously installed capacity, often with outdated technology, so that the appreciable increase in the value of exports was necessary to provide substantial increase in the physical volume of exports. One of the limitations of high rates of stronger growth in exports is low specialized export offer (result of decades of autarchic development).

In spite od that, if you look at the export performance in absolute terms it is clear that there are high rates of growth of exports of skill-intensive manufactures, as well as medium- and high-tech products, indicating that the value of exports of sophisticated products have significantly increased, in particular for the period 2000-08. Strong growth in exports of certain products in these countries suggests that the propulsive part of the industry is slowly being forged (industry generates more than $90 \%$ of exports). In industries from which these products originate that technological processes have been significantly improved while increase in production relies heavily on foreign orders.

One of the reasons for Balkan countries' weak export lies in industrial policy, which would be able to promote innovation, product quality and high technological standards in accordance with EU principles. New approach to employment policy regulations and an extensive re-organization of science and education system is needed. Institutional framework conditions for export (and import) expansion: the Stabilization and Association Agreement of the EU with individual countries, as well as the Central European free trade zone (CEFTA) are there.

\section{References}

Aydin, F. \& Saygili, H., (2007). Empirical Analysis of Structural Change in Turkish Exports. The Central Bank of the Republic of Turkey, October 2007. p. 47.

Camanho, N., Neto, C. \& Romeu. R., (2011), Did Export Diversification Soften the Impact of the Global Financial Crisis? IMF Working Paper, WP/11/99. p. 13.

Doanh, N., (2011). The Dynamic Patterns of Korea's Export Specialization. Thai Nguyen University of Economics and Business Administration, Vietnam. pp: 177198. http://home.sogang.ac.kr/sites/iias/iias04/Lists/b6/Attachments/60/6.pdf 
Nikolić G.: Tendency of exports technology structure and exports concentration in the..

IMF, 2011, Changing Patterns of Global Trade, Prepared by the Strategy, Policy, and Review Department. Approved by Tamim Bayoumi (June 15, 2011). p. 20. http://www.imf.org/external/np/pp/eng/2011/061511.pdf

Ivashko, A. \& Babson, C. (2012). Using a Country's Advantage in the European Union: A Study of Evolving Trade Structure in Eastern Europe, THE MICHIGAN JOURNAL OF BUSINESS. Volume 5 Issue 2, September 2012. pp: 47-106. Retrieved from http://michiganjb.org/issues/51/text51b.pdf

La, J., (2011), Correlations-Adjusted Export Market Diversification. Journal of East Asian Economic Integration. Vol. 15, No. 1, Spring 2011.

Mayer, J. \& Wood, A., (2001). South Asia's Export Structure in a Comparative Perspective, Oxford Development Studies, Vol. 29, No. 1, 2001. pp: 9-10. Retrieved from http://unpan1.un.org/intradoc/groups/public/documents/apcity/unpan002190.pdf

Munkacsi, Z., (2011), Export structure and export specialisation in Central and Eastern European countries, Budapest, Magyar Nemzeti Bank 2009. http://english.mnb.hu/Root/Dokumentumtar/ENMNB/Kiadvanyok/mnben_muhely tanulmanyok/mnben_op_81/op_81.pdf

Nikolić, G. (2010). Pokazatelji spoljnotrgovinske razmene Srbije sa svetom i EU, Zavod za udžbenike, Beograd. pp: 130-132.

Nikolić, G. (2011). Convergence of the Export Structure of Romania, Croatia, Serbia and BosniaHerzegovina to the Structure of Import Demand in Developed Countries, Panoeconomicus, 2011, 3, The Association of Economists of Vojvodina. pp: 394-405.

Saz, G., (2011), The European Integration of the Turkish Industry: A Trade Analysis. European Journal of Economics, Finance and Administrative Sciences-Issue 33 (2011), Center for Business Studies, University of Vienna, (pp: 102-105)

UN Publication, 2006. Standard International Trade Classification (Rev. 4), Department of Economic and Social Affairs, Statistics Division, UN, Statistical Papers Series M No. 34/Rev. 4, 2006. pp: X-XIII, 2-178.

UNDP (2011). Export Dependence and Export Concentration. p. 24-26. http://www.undp.org/content/dam/undp/library/Poverty\%20Reduction/Inclusive\% 20development/Towards\%20Human\%20Resilience/Towards_SustainingMDGPr ogress_Chapter1.pdf (retrieved by 14.12.2012)

Wood, A., (1994). North-South Trade, Employment and Inequality: Changing Fortunes in a Skill-Driven World. Oxford: Clarendon Press. 